\title{
THE FINANCIAL MANIFESTO OF THE ST PETERSBURG SOVIET, I90S
}

The appeal issued by the St Petersburg Soviet on December 1, 1905, and known as the Financial Manifesto, ${ }^{1}$ served as a pretext for the Witte Government to liquidate the Soviet and to start a counterattack which, in a short time, completed the defeat of the first Russian revolution. The Manifesto represents a unique attempt to further the objectives of revolutionaries by undermining the monetary system, but it did not inaugurate a new strategy for revolutionaries in Russia, nor has it influenced revolutionary movement elsewhere. The originality of the Manifesto lies in its advocacy of a set of actions designed to bring about the downfall of Tsarism by exerting pressure on the gold base of the monetary system and by undermining government credit, rather than through withholding of tax payments. Refusal to pay taxes has been a widely used political weapon, at least since the American Revolution. It found its place in the program of the British Chartist movement, one of the first political movements rooted essentially in the working class.

The authorship of the Manifesto, which is mentioned in practically all books dealing with the 1905 revolution, ${ }^{2}$ is generally ascribed to

1 Its full text can be found in numerous Russian sources, including S. N. Valk and associates, eds, 1905 God v Peterburge, I, Sotsial-demokraticheskie Listovki (Leningrad and Moscow, 1925), pp. 359-362; B. Radin [pseud. of B. Knunyants], Pervyi Sovet Rabochikh Deputatov (St Petersburg, 1906); D. Sverchkov, Na Zare Revolyutsii (Moscow, 1921); and Leon Trotsky, Russland in der Revolution (Dresden, 1909), pp. 202-204 (Russian version: 1905 God, in Sochineniya, II (Moscow, 1925)). An English translation of the Manifesto has become available only recently with the publication of Trotsky's 1905 (New York, 1972). It is deficient and omits a crucial paragraph. The author's translation, based on the text in 1905 God v Peterburge, is appended.

2 Not always correctly translated or interpreted; see, for instance, Howard D. Mehlinger and John M. Thompson, Count Witte and the Tsarist Government in the 1905 Revolution (Bloomington, 1972), pp. 141-142. E. H. Carr, The Bolshevik Revolution, Penguin ed. (London, 1966), II, p. 142, has confused the Financial Manifesto writh the Vyborg Manifesto (see below). 
Parvus (I. A. Helphand). ${ }^{1}$ This is true only in the sense that he presumably wrote the introductory analysis, in which his brilliant journalistic style is easily recognized. This is, however, not the part of the Manifesto which is usually mentioned. All elements of its appeal for action can be traced to the suggestions brought forward in the discussion which took place at a conference of the Peasants' Union held in Moscow November 6-10.2

The Peasant Union was organized at a constituent meeting held July 31 - August $1,1905,{ }^{3}$ and its leadership convened another conference to discuss problems of building an all-Russian peasant organization and to discuss means of action to achieve its primary goal transfer of all land to the peasants. The discussion on the latter point began on the third day (November 8 ) of the five-day meeting. ${ }^{4}$ The conclusion soon emerged that peasants should not hope to achieve their goal by violent action and that now, after the issuance of the October Manifesto, they must place their faith in a Constituent Assembly which would determine the future of Russia after the downfall of the Tsarist regime. But what could peasants contribute to that downfall short of a general peasants' strike, which was rejected by most delegates?

It was suggested by several delegates that the Government could be weakened by a refusal to supply recruits to the army, by withholding all kinds of taxes, by preventing the Government from issuing loans abroad or extending maturing obligations. Deprive the Government of

1 "approved the text of a 'financial' manifesto submitted by Parvus", Trotsky, 1905 , p. 225. Interestingly, the French translation (Paris, 1923), which appeared when Trotsky was fighting for his political future, omits the name of Parvus (p. 189), - Among the Western writers, Bertram B. Wolfe, Three Who Made a Revolution (New York and London, 1948), p. 328, identified Parvus as the Manifesto's author. So did J. L. H. Keep, The Rise of Social Democracy in Russia (Oxford, 1963), p. 240, but not Sidney Harcave, First Blood (New York, 1964), p. 232. The German biographer of Parvus, W. B. Scharlau, "ParvusHelphand als Theoretiker in der Deutschen Sozialdemokratie und Seine Rolle in der Ersten Russischen Revolution, 1867-1910" (unpublished Ph. D. thesis, University of Münster, 1964), has failed to trace and identify his leading role. His authorship is, however, noted in Z. A. B. Zeman and W. B. Scharlau, The Merchant of Revolution (London, 1965), p. 89. - It is worth noting that a history of the 1905 revolution by a leading Soviet historian published by the Communist Party publishing house Politizdat before the death of Stalin included Parvus among the three actual leaders of the Petrograd Soviet. See A. N. Pankratova, Pervaya Russkaya Revolyutsiya 1905-1907 g., second enlarged ed. (Moscow, 1951), p. 153.

2 All dates are old style.

- Uchreditelnyi S'ezd Vserossiiskago Krestyanskago Soyuza (Moscow, 1905).

- Protokoly Delegatskago Soveshchaniya Vserossiiskago Krestyanskago Soyuza, 6-10 Noyabrya $1905 \mathrm{~g}$. v Moskve (Moscow, 1906). 
resources! Proclaim abroad that no confidence should be placed in the Tsarist Government and no money lent to it! Tell foreign capitalists to refuse postponement of interest payments on outstanding loans and warn them that, once in power, the people will refuse to pay any arrears. It was also recommended that peasants should withdraw deposits from privately owned banks. Other delegates suggested stopping drinking alcoholic beverages to deprive the Government of the heavy excise taxes levied on them.

These suggestions came from delegates who were mostly peasants, but some were intellectuals, and these were identified as such in the minutes. There were also "guests" who were assisting peasants in their organizing drive (but the moderate "bureau" of the Congress prevented official representatives of the revolutionary parties from actively participating in the conference, and they left after an acrimonious debate). One of these guests mentioned that wealthy individuals were hurriedly transferring their capital abroad and suggested withdrawal of savings bank deposits. He added that "the Government fears the people, and a few resolute actions would be enough to force it to make concessions". 1

The general resolution adopted on the last day of the Conference covered a good deal of ground, but left it to the future Constituent Assembly to decide in which way the transfer of land to peasants who work it should be accomplished and was ambiguous on many political points. In tracing the origin of the Manifesto only point 7 is relevant. It reads in full:

'The Conference decides that to any persecution of the Peasants' Union, whose goal is to attain the people's objectives with a minimum of loss of lives, the Union will respond by a refusal to pay taxes and furnish recruits and reservists, ask for withdrawal of deposits and peasants' funds from savings and commercial banks, and close down all liquor shops."2

1 Ibid., p. 93. The mentioned proposals of delegates may be found on pp. 70, 71, 78 and 93.

${ }^{2}$ Ibid., p. 95. The wording of this point is quite awkward and reads, literally, that the Union will withdraw its savings deposits and peasants' capital. In the November 11 issue of Syn Otechestva, a daily published by the Party of Social Revolutionaries, a slightly different text appeared as part of a report on the Conference. The first point demanding the transfer of land to those working it was omitted. The passage quoted is thus listed as point 6 and the amendment quoted below as point 10. Minor differences in the text of point 10 and some other points may be due to errors in the telephonic transmission from Moscow to St Petersburg. 
An amendment was offered by a peasant delegate and adopted with one dissenting voice only, stating that

"The Convention of Delegates informs all those concerned that when the people obtains power, the representatives of the Peasants' Union in the Constituent Assembly will consider illegal, and therefore not subject to repayment, all loans raised by the Government after November 10, prior to [the convening of] the Constituent Assembly, and that it will consider any postponement of existing loans as new loans."1

The draft of the resolution adopted November 9 was submitted by the "Bureau" of the Conference, which succeeded in having it endorsed with virtually no changes. It reflected the moderate views of the Bureau of the Congress, which tried to discredit the revolutionary parties; the Menshevik Groman, in analyzing the resolution, went as far out as to claim that it reflected an antirevolutionary position of the Bureau's majority. In any case the delegates did not follow a suggestion to refuse payment of taxes and the supplying of recruits immediately, rather than only if the Union should be subject to persecution, and they endorsed the wording proposed by the Bureau. ${ }^{2}$

Two "representatives of the peasants of the Chernigov and Tomsk Gubernias" appeared before the Executive Committee of the St Petersburg Soviet the day before the arrest of its president, KhrustalevNosar', to ask for endorsement of the resolution of the Conference of the Peasants' Union. ${ }^{3}$ Was Parvus masquerading as one of them? Did he attend the Moscow Conference? Was he perhaps the "guest" who suggested the withdrawal of savings bank deposits?

1 Protokoly, p. 98.

2 See B. Veselovskii, Krest'yanskii Vopros i Krest'yanskoe Dvizhenie v Rossii (St Petersburg, 1907), pp. 74ff., for comments on the Convention and quotations from Groman's article in Moskovskaya Gazeta, 1905, No 5. Groman was an agricultural expert of the Mensheviks and later became a leading planner in the first years of the Soviet regime. See N. Jasny, Soviet Economists of the Twenties (Cambridge, 1972), the chapter "Vladimir Gustavovich Groman".

${ }^{3}$ The Okhrana colonel Gerasimov (1905 God v Peterburge, I, p. 113) refers to "two peasants". Protokoly mentions Chernigov but not Tambov gubernia as being represented at the Peasants' Union Congress. While all remarks by delegates appear in the Protokoly in a much condensed version, examination of those made by the delegates, none of whom is identified as an intellectual, from the Chernigov gubernia does not suggest that Parvus was one of them. It is, furthermore, likely that Parvus, who, except for one short trip, had not returned to Russia for 18 years and never had been exposed to a farm milieu, could have easily played the part of a peasant. Sverchkov mentions the representative of the Congress (p. 154), and on the following page states that the draft of the resolution was presented to the Soviet's committee (see below) by Parvus. 
It is highly unlikely that Parvus, who had returned to Russia at the very end of October, about two weeks after Trotsky, with whom he was closely associated at that time, came to St Petersburg, would have left the capital, where events were succeeding each other with breathtaking speed, for Moscow, where a Soviet was only in process of organization at the time of the Conference of the Peasants' Union. No reference to a trip by Parvus to Moscow could be found. It is most likely that he merely decided to make his own the conditional action program of the Conference, which was reported in the press or about which he learned from one of the professional revolutionaries who had attended as "guests".

What did make these proposals so attractive to Parvus - and to the Soviet? Parvus, was looking feverishly for an opportunity to become active - at least behind the scenes - in one of the organizations operating in the open that were springing up after the issuance of the October Manifesto, which would offer an opportunity to push "the masses" into additional actions. At the same time the Soviet was in a quandary. The Tsarist regime was counterattacking and the forces of the revolution were ebbing, as clearly demonstrated by the faltering strike movement. Those elected at the meeting of November 27 to replace the original leadership of the Soviet, arrested on the previous day, were realistic enough to reject a political strike to protest against the arrests. The revolutionary parties and a majority of the delegates to the Soviet were looking for spectacular action which, short of an armed insurrection, would galvanize the forces of revolution; a mass action to exert pressure on the government by initiating a run on the official gold stock, much of which was held abroad to facilitate foreign borrowing by the Tsarist government.

The recognition that a monetary system with free and unlimited convertibility of paper currency into gold coin was vulnerable to massive withdrawals provided a new possibility for direct action. Moreover, a banking system comprising a national network of stateowned savings banks provided an additional opportunity to put pressure on the official gold stock. Furthermore, the debate about the role of gold in the monetary system, introduced only a few years earlier (1897), was still very much in the public mind. It is quite possible that Parvus, who had already formulated the theory of a permanent revolution and who believed that the Tsarist regime was on the brink of financial bankruptcy, actually expected that the kind of action outlined in the Manifesto would precipitate a crisis. ${ }^{1}$ It will

I Parvus subsequently devoted considerable attention to the role of banking and, in particular, of the large mixed (deposit-investment) banks, in furthering 
be shown later that while the real financial position, and in particular the decline in the gold stock, was indeed critical, the pertinent data were kept secret and the revolutionaries never suspected upon how deadly a weapon they had stumbled.

Thus, the urge to do something quickly in response to the arrest of Khrustalev-Nosar', the fiery oratory of Trotsky and Parvus, and the lack of feasible alternatives, all combined to focus the leadership of the Soviet on what has entered history as its Financial Manifesto. The events leading to its adoption can be reconstructed as follows.

The Manifesto was a further elaboration of a resolution adopted a few days earlier (November 22) by the Executive Committee of the Soviet, still presided over by Khrustalev-Nosar'. The resolution claimed that "in view of the impending bankruptcy of the State, it was necessary for the working class and all poor classes of the population to withdraw their deposits from the savings banks [which were operated by the government] and to demand that all payments, including wages, be made in full-bodied coin". ${ }^{1}$ On the same day, the Executive Committee converted 10,000 rubles of the Soviet's funds into gold coins. ${ }^{2}$ The decision to follow up this resolution by an appeal to the peasants was not put into effect, since the commission appointed to draft it was scheduled to meet on November 26 , the day on which Khrustalev-Nosar' was arrested.

Immediately after the election of the new presidium of the Soviet on November 27, Trotsky (who was operating under the name of Yanovskii) proposed that it make public a manifesto along the lines of the resolution of the Peasants' Union Congress. Several speakers supported the proposal, including "some individual" who claimed to represent the Congress and offered to participate in the drafting of such an Appeal to the People. ${ }^{3}$ The drafting was entrusted to a commission with the stipulation that four specific recommendations addressed to the peasants should be included:

the concentration of business and of their potential use for controlling industry in economically advanced countries. See Zeman and Scharlau, p. 41, and Parvus, Die Banken, der Staat und die Industrie (Dresden, 1910) and Die Verstaatlichung der Banken und der Sozialismus (Berlin, 1919).

1 Nachalo, 1905, No 8. Also Deutscher, p. 242.

2 Testimony of A. N. Rostruev, in N. I. Sidorov, ed., 1905 God v Peterburge, II, Sovet Rabochikh Deputatov (Leningrad, 1925), p. 185.

3 Testimony of F. F. Shanyavskii preceding the trial of the Soviet leadership, ibid., pp. 199-200. See also testimony by N. F. Olshanskii, ibid., pp. 196ff., who referred to the delegate as a "short, nimble Jew" (p. 202). 
1) refusal to pay redemption payments on land, 1

2) refusal to pay taxes,

3) refusal to accept paper money, and

4) withdrawal of savings bank deposits.

The commission consisted of the Presidium of the Soviet (Trotsky, Sverchkov and Zlydniev), with the representatives of the three revolutionary parties taking part without being officially coopted. ${ }^{2}$ The Manifesto was drafted hastily, since the new Presidium knew that the days of the Soviet were numbered. It was approved by the "editorial commission" on December 1, and the Presidium sent it immediately to the press, without submitting the text to the full Soviet for approval.

In addition to the signatures of the "Soviet of Workers' Deputies" (without identification of the city), the Manifesto bore also those of the Main Committee of the All-Russian Peasants' Union, the Central Committee and the Organization Committee of the Social-Democratic Workers' Party of Russia (i.e., of the central bodies of the Bolsheviks and of the Mensheviks, respectively), of the Central Committee of the Party of Social-Revolutionaries and of the Central Committee of the Polish Socialist Party (PPS). It was subsequently endorsed by the Bund and, on December 4, by the Moscow Soviet which gave it a wide distribution.

More than two thirds of the 600-word Manifesto, the full text of which may be found in the Appendix, is devoted to the analysis of the financial position of the government and of the economic situation arising from it, which has attracted scant attention from Western students who have focused on the program of action.

The charge by the Executive Committee suggests that the Manifesto

1 The report of the Okhrana erred on this point: Colonel Gerasimov referred to payments to landowners (obrok) while the Manifesto refers to payments to government banks for land transferred to peasants as a result of the 1861 reform (vykupnye platezhy). Gerasimov, furthermore, noted that at its meeting on November 25 the Executive Committee debated "how to use the limitations of the money market [sic] to further the goals of the revolution". 1905 God $v$ Peterburge, II, pp. 113 and 115 , respectively.

2 Sverchkov, p. 154. Sverchkov, who, under the pseudonym of Vvedensky ran against Trotsky for the chairmanship of the Soviet on November 27 and was defeated by a few votes, was of noble origin, maintained during the revolution a neutral position between the two wings of the social-democratic party, but later became a member of the communist party. Sverchkov, pp. 3-4 and 8 . Sverchkov recollected that the "draft of the manifesto was submitted by Parvus and adopted with my and Trotsky's amendments" (p. 155). There is no evidence that the commission formally coopted Parvus, although it had the right to do so, 
was to be aimed at the peasantry; in fact, however, it was addressed to the entire population of Russia, although the fact that it originated in a congress of peasants is clearly discernable. The analysis of the economic situation begins with a discussion of the plight of the peasants; some other parts, however, read almost like a program of an opposition party expecting to come into power and outlining a responsible financial program to cope with a desperate situation. It makes no specific reference to the economic strikes which were sweeping the country.

The appeal to action is preceded by an analysis of the financial position of the government. The general economic situation is characterized in a few cryptic sentences. The suggested common cause of the economic depression is the drying up of foreign loans, which financed much of construction and production, and the flight abroad of Russian capital. Some parts of the analysis are pure fantasy ("For a long time the government has been spending all state revenue on the army and navy") or wishful thinking ("Revolts of the poverty-striken, hungry troops are flaring up all over the country"). The revolutionary upheaval is made to appear as a reaction to the financial irresponsibility of the government.

The call for action ("We have therefore decided...") again begins by steps to be taken by peasants. Interestingly enough (and contrary to what can be found in some Western summaries of the Manifesto), there is no direct appeal for stopping paying taxes. An indirect reference can be read into the admonition, clearly addressed to peasants, to "refuse to make land redemption [vykupnye] payments and all other payments to the Treasury". There could have been several reasons for not mentioning taxes (contrary to the instructions of the Executive Committee; see above, p. 22), such as the fact that workers paid no income or other direct taxes. It would have been impractical to call for a refusal to pay indirect taxes, such as excise taxes embodied in a large number of food and drink items.

The other "decisions" were in line with the appeal of the Executive Committee: to require settlement of all transactions, including wage payments, in gold, and, when the amount was less than five rubles (the smallest gold coin), in silver coin, and to withdraw savings bank deposits and balances with the State Bank, insisting in both cases on payment in gold coins. The Manifesto concludes with the "decision" not to "permit the repayment of loans which the Tsarist government has contracted while it was clearly and openly waging war against the entire people". This vague formulation was the result of a compromise. One of the members of the editorial committee, Sverchkov, suggested a general warning that debts contracted by the government after 
issuance of the Manifesto would not be recognized, while the representative of the Peasants' Union insisted that the critical date should be November 10, on which day their congress had adopted a resolution which included the warning on Tsarist debts. Since the majority of the editorial committee felt that a retrospective date was not proper, a vaguely worded phrase was adopted. ${ }^{1}$

The government was sufficiently alarmed to issue a statement which conceded, referring to the Manifesto, that "this agitation has not remained without effect on savings bank depositors and withdrawals have increased". It announced that the staffs of savings banks would be reinforced to handle the increased operations and went on to assure depositors that they would not suffer any losses if savings banks were plundered by the revolutionaries and that there was more risk in keeping withdrawn cash at home than in leaving deposits undisturbed. ${ }^{2}$

The publication of the Manifesto on December 2 by eight liberal St Petersburg newspapers led to their immediate closing. ${ }^{3}$ The immediate political effect of the Manifesto was to provide the government with a plausible justification to dissolve the Soviet by sending a military detachment to occupy the hall in which it was meeting and to arrest its leaders. ${ }^{4}$ The trial against the two successive sets of leaders of the Soviet opened in May 1906. The indictment followed closely the depositions of one of the delegates to the Soviet, Shaklyarovskii. It

1 Sverchkov, p. 158.

2 Leon Trotsky, ed., Istoriya Soveta Rabochikh Deputatov g. S.-Peterburga (Moscow, 1906), pp. 192-193. At the trial of the leaders of the Soviet, the Public Prosecutor, V. Bal'ts, stated that the Manifesto had had "some effect" as the inflow of funds into savings banks declined "in December by 94 million rubles below normal". 1905 God v Peterburge, II, p. 404. This figure is somewhat higher than the difference derived from the figures given in the table on p. 26, but perhaps he used a different period for "normal".

3 And not merely "seizure", as stated by Deutscher (p. 142). The list of the metropolitan newspapers which published the Manifesto may be found in 1905 God v Peterburge, II, pp. 81-82. See also A. Morskoi [pseud. of V. I. Shtein], Iskhod Rossiiskoi Revolyutsii 1905 Goda i Pravitelstvo Nosar'ya (Moscow, 1911), p. 94. The radical Russkaya Gazeta published only the analytical part of the Manifesto, and Trotsky and Parvus resigned in protest from its editorial board (Scharlau, p. 229, note 48). All other papers were warned by the government that they would be shut down if they published the Manifesto (p. 94). The Manifesto was also distributed as a one-page leaflet.

4 Parvus escaped arrest at that time, but was jailed later. He devoted much time in his subsequent exile to the study of finance and by 1910 formulated a theory assigning the banking system a key role in building a socialist society, a theory which Lenin subsequently advanced in his Imperialismus, which appeared shortly before the February revolution. See George Garvy, "The Origins of Lenin's Views on the Role of Banks in the Socialist Transformation of Society", in: The History of Political Economy, Spring 1972. 
accused the leaders of the Soviet of having tried, by issuing the Manifesto, to undermine the government's credit and to deprive it of its gold stock, which provided the basis for sound finance. ${ }^{1}$

When, almost eight months after the issuance of the Manifesto, the Tsar dissolved the first Duma, the liberal and socialist deputies, caught by surprise, had no prepared action program. Those deputies who met on the following day (July 9, 1906) in Vyborg issued on the second and last day of their deliberations a short manifesto; its appeal for action followed closely the Financial Manifesto. It proclaimed that there was "a sure means" to "prevent Russia now from being even one day without a popular representation".

"The government has no right to collect taxes and to draft into military service without the assent of a popular representation. Therefore, now that the government has dissolved the representation of the people, it is your right to refuse it both soldiers and money. If, in order to obtain resources, the government will borrow, the people will consider illegal loans raised without the assent of the popular representation and will not repay them.

Thus, without a popular representation do not give a single kopek to the Treasury and not a single soldier to the army."2

The Vyborg appeal had no more effect than the Manifesto from which it drew its inspiration.

Immediately after the revolution, the Russian socialists, at least those abroad, tended to play down the importance of the Manifesto. ${ }^{3}$ Official Soviet historiography claims that "the Manifesto made sense only as a preparatory step toward an armed insurrection" and stresses that Lenin cited it merely "as one of the examples of partial realization in an embryonic form of the bloc (alliance) of the proletariat with the peasants".4

11905 God v Peterburge, II, p. 281.

2 "Pervaya Gosudarstvennaya Duma v Vyborge", prepared for publication by A. A. Sergeev, in: Krasnyi Arkhiv, LVII (1933), pp. 97-98. Some alternative language crossed out in the preserved original draft.

- Neither Julius Martov, "Der Staatsstreich in Russland"; in: Die Neue Zeit, XXV, 2 (1907), pp. 516-528, nor Leon Trotsky, “Der Arbeiterdeputiertenrat und die Revolution", ibid., pp. 76-86, writing immediately after the defeat of the revolution, mention it. It is, therefore, not surprising that Oskar Anweiler, Die Rätebewegung in Russland, 1905-21 (Leiden, 1958), refers to it only in passing (p. 74). Trotsky's statement at the trial of the leaders of the Petrograd Soviet that the actions advocated in the Manifesto were meant to be "temporary" should be interpreted as an attempt to obtain a less severe verdict.

- Pankratova, p. 153. 

Changes in Deposits in Government Savings Banks during
the Month of December (in millions of rubles)

\begin{tabular}{lcrcrr} 
& \multicolumn{2}{c}{ In St Petersburg } & \multicolumn{2}{c}{ Outside St Petersburg } \\
& Avg. 1902-04 & 1905 & Avg. 1902-04 & 1905 \\
Deposits & 1.8 & 1.5 & 31.9 & 32.0 \\
Withdrawals & 1.5 & 5.6 & 28.0 & 117.0
\end{tabular}

Source: P. Gorin, Ocherki po Istorii Soveta Rabochikh Delegatov v 1950 Godu, second ed. (Moscow, 1933), p. 308.

Evaluation of the effect of the Manifesto by both sides was based largely on the interpretation of a table on gross transactions of the savings bank system released by the authorities. As shown in this table, new deposits in savings banks declined slightly in St Petersburg when compared with the average of the three preceding years; they were virtually unaffected elsewhere. Withdrawals increased substantially in December in as well as outside St Petersburg, in the latter case by more than four times, as compared with the 1902-04 average. Yet the Manifesto had remained unknown in many parts of Russia because of the paralysis of transportation and communications. While the leadership of the Soviet later claimed, on the basis of the data summarized in the table, that its appeal had evoked widespread response, it is probable that to a large extent the rise in withdrawals was caused by spreading uncertainty and fear, since a large part of the deposits belonged to members of the middle class rather than to workers. The need of the striking workers to dip into reserves is likely to have been another contributing factor.

While the savings banks figures lend themselves to a variety of interpretations and the amounts involved are altogether modest, pressure from other sources on the official gold stock became considerable after the proclamation of the general strike and the formation of the St Petersburg Soviet. Obviously, under the circumstances prevailing at the time it is well-nigh impossible to assign the rise of withdrawals to any single factor. The whole chain of events which began with the desastrous course of the Japanese war, the subsequent widespread unrest which found its expression in the Zemstvo Conference of November 1904, the Bloody Sunday, the student movement, the Potemkin revolt, peasant uprisings and, finally, the general strike, shook the very foundations of the Tsarist regime. These shock waves immediately reached the financial markets of Western Europe in which the Russian government had been floating (and refunding) huge loans. Foreign holders of Russian securities became uneasy, and 
prices of Russian stocks and bonds declined on foreign stock exchanges. However, it is impossible to assign to the Manifesto any specific role in this reassessment of the safety of investments in Tsarist Russia or its weight in the reaction of domestic holders of wealth to the first revolutionary wave that swept over the Empire.

Documents published half a century after issuance of the Financial Manifesto show how close to financial collapse the Tsarist regime was towards the end of 1905 as a result of the strains caused by the war with Japan, but even more by the panicky reaction of the men of wealth to the revolutionary events. ${ }^{1}$ Neither the underlying facts (in particular with regard to the flight of capital from Russia) and the decline of the official gold stock for this and other reasons, nor the deep concern which it caused in the Ministry of Finance were known to the general public. In retrospect, the impact of withdrawals of gold coin from the State Bank and Treasury offices and of the hoarding of those in circulation as a result of the general uncertainty appear to have been a considerable and a much more significant influence than withdrawals from savings banks in response to the Manifesto, but they lend substance to the Manifesto's claim that the government's financial position was critical.

The revealing confidential memoranda of the Finance Committee, which included the Minister of Finance and Timashev, the head of the State Bank, were published only in 1955 and 1956. These documents, providing a dramatic account of the deteriorating financial position of the government, were transmitted immediately to Tsar Nicholas II to impress him with the gravity of the situation. They led the Soviet

1 A. L. Sidorov, ed., "Finansovoe Polozhenie Tsarskogo Samoderzhaviya v Period Russko-Yaponskoi Voiny i Pervoi Russkoi Revolyutsii", in: Istoricheskii Arkhiv, 1955, No 2, pp. 121-149; "Denezhnoe Obrashchenie i Finansovoe Polozhenie Rossii (1904-07 gg.)", ibid., 1956, No 3, pp. 88-123. The first contains six documents from the archives of the Ministry of Finance with a four-page introductory note by Sidorov, while the second consists of the "Memorandum of the Chairman of the Board of the State Bank, S. I. Timashev, on Monetary Circulation in Russia, 1904-1907", dated February 12, 1907 (from the Central State Historical Archive, Leningrad) with a similarly short introduction. The captions for the various memoranda and other documents were clearly supplied by the editor. The statistical data cited in Timashev's memorandum are from the Ezhegodnik (Annual Report) of the Ministry of Finance for 1905, published in 1906. The most important documents included in the first article are a memorandum of December 5, 1905 (the third day following the publication of the Manifesto) on the possible need for suspending conversion of paper currency and a memorandum by the Minister of Finance on the need to protect the official gold stock. Sidorov remarked in a footnote to the first article that "neither historians, nor economists have studied this aspect [the deterioration of the financial position of the government] of events". 
historian Sidorov to the conclusion that at the end of 1905 and the beginning of 1906, finances of the Tsarist government were in a "catastrophic state", that suspension of the conversion of paper money into gold was averted only by a number of emergency measures, and that payments in gold or foreign currency shortly due to foreign holders of Russian loans and other obligations were so large that only flotation of a new loan had saved the regime from bankruptcy.

The over-all picture of the impact of the revolutionary events on the gold stock and monetary circulation emerges from Timashev's memorandum written more than a year after the event. The immediate consequences of the Japanese war on the government's finances and on monetary circulation were quite small, and Timashev characterizes the first ten months of 1905 as "normal". As a matter of fact, the official gold stock increased by 141.8 million rubles, in part as a result of instructions issued by the State Bank as early as February 1904, at the outbreak of the war, to honor withdrawal orders with paper currency and to issue gold coins only on specific request. The discount rate was raised in November, in two steps, by $1 \frac{1}{2}$ percent (and by another one percent after the crisis had passed - on January 9, 1906). One of the purposes of raising the rate was to limit issuance of currency and to force gold out of hoards; Timashev found that it had failed in this purpose. The memorandum also noted that "beginning in October, as a result of the agitation by the extremist parties, demands for payment in gold increased when the [State] Bank discounted bills or honored withdrawal orders".

The local State Bank offices paid out gold on request, but, in order to avoid their running out of supplies, 70 million rubles in gold coins had to be shipped to offices outside St Petersburg. Shipments were gradually reduced and stopped altogether to avoid a critical depletion of the official gold stock. Indeed, a calculation made on December 8 showed that near-term maturities to foreign banks amounted to 252 million rubles, while the official gold stock totaled 1,076 million rubles; other estimates placed total near-term potential foreign claims on gold at as much as 401 million, or 37 percent of the remaining gold holdings. ${ }^{1}$ In the first 10 days of December alone, the gold stock had declined by 50 million rubles.

Gold losses were in part caused by the "panic which seized capitalists" (Timashev's words) and which had resulted in the hoarding of gold coin and in the transfer of funds abroad (which, under the existing arrangements, involved use of the official gold held abroad, mainly in Paris, for buying foreign exchange for private account). In November

1 "Finansovoe Polozhenie", loc. cit., pp. 128 and 135. 
and December of 1905 alone, net sales of foreign exchange required selling 58.1 million rubles of gold from the official stock. Total official gold losses during these two months amounted to the "colossal sum" of 251.5 million.

A circular was issued by the head office of the State Bank to branches two days after the publication of the Manifesto urging them to limit payments in gold (including those to meet withdrawals from savings banks due to "agitation"). Because of strikes, it did not reach all offices and on December 31 a telegram was sent to State Bank and Treasury offices urging them to pay out gold sparingly. A special subcommittee was set up by the Finance Committee (of senior officials of the Ministry of Finance) following the publication of the Manifesto to keep an eye on the gold situation and to recommend any measures that might be required.

After the suppression of the St Petersburg Soviet and of the opposition press, the gold situation, which made the government consider suspending conversion - Witte, who formerly had served as a Minister of Finance, was emphatic on this need -, improved rapidly. In January 1906 the outflow declined and finally stopped, and branches were able to return to the head office of the State Bank not only the 70 million rubles shipped to them as an emergency measure, but also an additional 160 million rubles. As early as January 6, a joint meeting of the Finance Committee and the Department of the National Economy noted a cessation of withdrawals from savings banks and a slow increase in deposits in St Petersburg and in some other cities; ${ }^{1}$ yet heavy purchases of foreign exchange continued through August 1906 (that is, until just after the dissolution of the Duma). Ultimately, confidence in paper money was reestablished and the external position of the ruble was strengthened, shored up by a new foreign loan to the Tsarist regime. ${ }^{2}$ The revolutionaries never learned how seriously the financial position of the government was weakened during the closing months of 1905.

1 Ibid., p. 143.

2 See James William Long, "Organized Protest Against the 1906 Russian Loan", in: Cahiers du Monde Russe et Soviétique, XIII (1972), pp. 24-39, for an account of the campaign of Russian revolutionaries and democrats of various persuasions, supported by the French Socialists, to prevent floating of Russian loans in France. See also Olga Crisp, "The Russian Liberals and the 1906 Anglo-French Loan to Russia", in: The Slavonic and East European Review, XXXIX (1960-61), pp. 497-511. 


\section{APPENDIX}

\section{MANIFESTO}

The government is on the brink of bankruptcy. It has reduced the country to ruins and scattered it with corpses. The peasants, worn out by suffering and hunger, are incapable of paying taxes. The government has used the people's money to make loans to the landowners. Now it is at a loss as to what to do with the landowners' mortgaged estates. Factories and plants are at a standstill. There is no work. Trade stagnates everywhere. The government has used the capital obtained through foreign loans to build railways, warships, and fortresses and to accumulate arms. Foreign sources have now been exhausted, and state orders have also come to an end. The merchant, the supplier, the contractor, the factory owner, accustomed to enriching themselves at the Treasury's expense, find themselves without profits and are closing down their offices and plants. One bankruptcy follows another. Banks are collapsing. All trade transactions have been reduced to the barest minimum.

The government's struggle against revolution is causing uninterrupted unrest. No one is any longer sure what the morrow will bring.

Foreign capital is going home. "Purely Russian" capital is also flowing into foreign banks. The rich are selling their property and going abroad in search of safety. The birds of prey are fleeing the country and taking the people's property with them.

For a long time the government has been spending all state revenue on the army and navy. There are no schools. Roads have been neglected. In spite of this, there is not enough money even to keep the troops supplied with food. The war was lost partly because military supplies were inadequate. Revolts of the poverty-stricken, hungry troops are flaring up all over the country.

The finances of railways are disorganized because of the government's neglect. Many millions of rubles are needed to restore the economic soundness of railways.

The government has pilfered the savings banks, and handed out deposits to support private banks and industrial enterprises, which often are entirely fictitious. It is using the small saver's capital to play the stock exchange, where that capital is exposed to daily risk.

The gold reserves of the State Bank are insignificant in relation to commitments on government loans and the requirements of trade turnover. It will be reduced to dust if gold coin is demanded in all transactions.

Taking advantage of the absence of any accountability for state 
finances, the government has long been obtaining loans which far exceed the country's ability to pay. With new loans it is covering the interest on old ones.

Year after year the government prepares false estimates of revenues and expenditures, showing both to be less than they are in reality and fleecing indiscriminately so as to show a surplus instead of an annual deficit. Officials are free to rob the already depleted Treasury.

Only the Constituent Assembly, after the overthrow of the autocracy, can halt this financial ruin. It will carry out a severe investigation of state finances and will draw up a detailed, clear, accurate, and verified estimate of state revenues and expenditures (budget).

Fear of popular control which will reveal to the entire world the government's financial insolvency is forcing it to keep putting off the convening of the people's representative assembly.

The autocracy is responsible for the financial bankruptcy of the state, as it is for the military bankruptcy. The people's representative assembly will have only the duty of paying off the debts as promptly as possible.

In order to safeguard its rapacious activities the government forces the people to engage in a deadly struggle with it. Hundreds of thousands of citizens are perishing and are ruined in this fight, and industry, trade, and means of communication are destroyed at their very foundations.

There is only one way out - to overthrow the government, to deprive it of its last forces. It is necessary to cut the government off from the last source of its existence: financial revenue. This is necessary not only for the country's political and economic liberation, but also, more particularly, to restore order in government finances.

We have therefore decided:

To refuse to make land redemption payment and all other payments to the Treasury. In all transactions and in the payment of wages and salaries, to demand gold, and in the case of sums of less than five rubles, fullweight coin.

To withdraw deposits from the state savings banks and from the State Bank, and to demand payment of the entire amount in gold.

The autocracy has never enjoyed the people's confidence and has never received any authority from the people.

At the present time the government is behaving within the frontiers of its own country as though it were ruling a conquered country.

We have therefore decided not to permit the repayment of loans which the tsarist government contracted while it was clearly and openly waging war against the entire people. 
The Soviet of Workers' Deputies

The Main Committee of the All-Russian Peasants' Union

The Central Committee and the Organization Commitree of the Russian Social-Democratic Workers' Party

The Central Committee of the Party of Social-Revolutionaries

The Central Committee of the Polish Socialist Party (P.P.S.) 